\title{
Love Thy Neighbor-But Does that Include a Six Hundred Eighty-Four Cow Dairy Operation? A Survey of Community Perceptions
}

\author{
J. M. Smith, ${ }^{* 1}$ R. L. Parsons, $\dagger$ K. Van Dis, $\dagger^{2}$ and G. N. Matiruł \\ *Department of Animal Science, University of Vermont, Burlington 05405 \\ †Department of Community Development and Applied Economics, University of Vermont, Burlington 05405 \\ łIndependent Research Consultant, Williston, VT 05495
}

\section{ABSTRACT}

The juxtaposition of nonfarming residences to operating dairy farms often precipitates conflict over appropriate land use. This was the situation facing the residents of the town of Charlotte, Vermont, in 2002 when a local dairy farmer proposed expanding from 225 to 684 cows with the construction of a new dairy facility and manure storage lagoon. The proposal raised considerable concern within the community and presented a unique opportunity for extension researchers to examine and analyze the attitudes and concerns of local residents toward the planned expansion, including their reasons for supporting or opposing the expansion, and to develop recommendations for farm operators considering future expansions. A survey instrument was developed and inserted in a local newspaper that was delivered to all households of Charlotte to identify important concerns of the community and explanatory factors differing between supporters and nonsupporters. Of those responding to the survey, 44.3\% opposed the proposed dairy facility, $30.6 \%$ supported it, $17.9 \%$ needed more information to make a decision, and $7.2 \%$ had no opinion or were unaware of the proposal. There were no significant demographic (age, gender, educational attainment) differences between supporters and nonsupporters. Yet, the closer the proximity of the respondent's residence to the farm, the more likely he or she was to oppose it $(\beta=1.018)$. The concerns of greatest importance were water quality (4.42/5), effect on property values (3.07/5), and animal welfare (3.58/5). Responses to the open-ended questions on the survey revealed strong views toward the farmer personally as well as concentrated animal feeding operations in general. The results indicate that farmers and extension need to take proactive steps to provide education and infor-

Received September 18, 2007.

Accepted November 27, 2007.

${ }^{1}$ Corresponding author: Julie.M.Smith@uvm.edu

${ }^{2}$ In partial fulfillment of MS degree conferred October 2006. mation relevant to the facts and issues surrounding new dairy facilities for 500 to 700 dairy cows.

Key words: confined animal feeding operation, dairy farm, land use conflict, community conflict

\section{INTRODUCTION}

Conflicts over land use are increasing between agriculture and residential neighbors as more farms are becoming surrounded by nonfarming neighbors. According to the US Census of Agriculture (USDA, 2002), over one-third of the nation's farmland is now located within or adjacent to metropolitan areas. This can pose a challenge for dairy farmers whose economic survival depends on expanding or modernizing their operations. Nonfarming neighbors often oppose such changes, citing concerns over water and air pollution and other negative externalities from the farm that may interfere with the enjoyment of their property. A proposed new dairy facility in Charlotte, Vermont, presented a unique opportunity to study the aspects of community conflict over the establishment of 500to 700-cow dairy operations through a survey of community members.

Charlotte is a rural community with a population of 3,569 (US Census Bureau, 2000) and land area of 107.4 $\mathrm{km}^{2}\left(41.5 \mathrm{mi}^{2}\right)$ immediately south of the most densely populated area of the state. All residents live within $9.7 \mathrm{~km}(6 \mathrm{mi})$ of the proposed dairy facility. The dairy farmer proposed to increase herd size from 225 to 684 milking cows and construct a new barn and manure storage facility on a site away from existing facilities. Many Charlotte residents voiced their opposition in local media and at town meetings. A community group called Citizens for Safe Farming (CFSF) was formed, and the group initiated legal action against the farmer, seeking to stop the construction of the new facility (CFSF, 2003). In the legal suit, residents cited environmental concerns over water pollution and their perceived inaction by the Vermont Agency of Natural Resources. Members of CFSF objected to the proposal 
based on its potential to increase noise, traffic, odor, and other nuisances (CFSF, 2003).

The Vermont Agency of Agriculture, Food and Markets (VAAFM) is responsible for issuing permits for large farm operations (LFO; i.e., farms with more than 950 animal units of horses, cattle, or sheep in Vermont). The permit requirements are outlined in the state's LFO law adopted in 1996 and revised in 2000. This law meets the requirements of the federal Environmental Protection Agency, which provides oversight for regulating water quality associated with concentrated animal feeding operations (CAFO). Vermont's LFO program established design and operating standards to ensure that farmers obtaining LFO permits meet or exceed the technical CAFO requirements (VAAFM, 2001).

The farmer submitted his permit application to VAAFM for a proposed 684-cow plus 416-replacement heifer operation with a new $5,574-\mathrm{m}^{2}\left(60,000 \mathrm{ft}^{2}\right)$ barn and 0.69-ha (1.7 acre) manure pit designed with a storage capacity of $240 \mathrm{~d}$ (Van Dis, 2006). As part of the application, the farmer was required to use his best judgment and indicate whether he believed the proposed facility would generate more odors, noise, insects, flies, or other pests compared with other similarly sized farms with the same type of animals (VAAFM, 2001).

Nutrient management and prevention of environmental pollution are 2 requirements of CAFO. When manure is overapplied, $\mathrm{N}$ and $\mathrm{P}$ can potentially pollute ground and surface water (Gollehon et al., 2001; Aillery et al., 2005). Charlotte is located along the shores of Lake Champlain, which has P levels exceeding Vermont's water quality standards (Environmental Protection Agency, 2006). Research by the Lake Champlain Basin Program identified dairy farms located in Addison, Chittenden (location of this specific farm), and Franklin counties as significant sources of nonpoint $\mathrm{P}$ loading of the lake (Lake Champlain Basin Program, 2006).

Although properly constructed manure lagoons protect water quality, they release volatile organic compounds such as ammonia, which adversely affect air quality (Lefcourt and Meisinger, 2002; Aillery et al., 2005; Kryvoruchko et al., 2006). Flies and other insects as well as rodents and other vermin are attracted to stored manure and can multiply to nuisance levels. Although the VAAFM does not require permit-seekers to obtain input from neighbors on these or any other matters, several studies showed that negative externalities constitute the main reasons why residents oppose the location of CAFO in their neighborhood (Jones et al., 2000; Kelsey and Vaserstein, 2000).
The events in Charlotte provided a unique opportunity for examining the factors underlying conflict between local residents and a dairy farmer seeking to consolidate and expand his operations. Although several studies examined conflict issues between farmers and nonfarm residents over land use (Jones et al., 2000; Kelsey and Vaserstein, 2000; Vaserstein and Kelsey, 2000), the authors could not identify studies in the literature that focused specifically on the dairy industry, so this study was undertaken to do so.

The 3 key objectives of this study were to: 1 ) determine if there were any significant demographic characteristics distinguishing residents who opposed the farmer's proposal from those who were in support; 2) identify the critical issues of concern to residents with regard to the proposal for a modernized, large dairy facility and how these concerns influenced individual decisions to support or oppose the plan; and 3) assess whether there were overarching or fundamental values, perceptions, or attitudes that may influence individual decisions to support or oppose the farmer's proposal.

\section{MATERIALS AND METHODS}

\section{Study Hypotheses and Conceptual Framework}

Six study hypotheses pertinent to the land use conflict in the town of Charlotte emerged.

1. Sociodemographic factors affect an individual's support for the proposed facility. These factors may include gender, level of education, number of years a resident in Charlotte, the number of months spent in Charlotte throughout the year, ownership vs. rental of residence, and acreage of land associated with the residence.

2. Residents living within $1.6 \mathrm{~km}(1.0 \mathrm{mi})$ of the proposed facility are less likely to support it than residents living more than $1.6 \mathrm{~km}(1.0 \mathrm{mi})$ away.

3. Residents having environmental concerns (water quality, manure storage, and pesticide usage) are less likely to support the proposed dairy facility.

4. Residents concerned with the effect of the LFO on their view or property value are less likely to support the proposal.

5. Residents who express animal welfare concerns are less likely to be supportive of the proposed dairy facility.

6. Residents are more concerned about environmental factors than they are about economic factors.

\section{The Survey Instrument}

Based on the 6 study hypotheses, we designed a survey instrument to obtain information on the factors 
that influenced the opinion of residents regarding the dairy farm proposal (supported, opposed, or undecided/ needed more information). The survey contained 24 questions, including ordinal, Likert scale, fill-in-theblank, and open-ended questions (see appendix). The survey was distributed as a 1-time insert in a local newspaper delivered to all Charlotte households. The instructions requested that the survey be completed by the household member over age 18 whose birthday was closest to the date of the survey's receipt. Of 1,500 surveys mailed, $20.3 \%$ were returned, and 294 valid responses were tabulated. The use of a newspaper insert survey ensured our reaching all households in Charlotte but precluded a second mailing because of the potential risk of generating duplicate responses.

\section{Data Analysis}

Only data from responses indicating opposition, support, or the need for more information were included in the analyses. Thus, all data were excluded from the $7.2 \%$ of respondents who had no opinion or were unaware of the proposal based on question 12. The first step in data analysis was to determine whether there were any significant differences between residents who supported the farm proposal, those who did not support it, and those who said they needed more information based on sociodemographic variables, economic and environmental concerns, farming experience, and the sources residents found more reliable for information on agriculture and land use issues. A Student's $t$-test (Agreseti and Finlay, 1997) was used to determine variables that differed among the 3 categories of respondents (support, do not support, need more information) by pairwise comparison.

The second step was to determine which responses, if any, were highly correlated and multicollinear, implying that these questions represented the same issue or concern and therefore should be evaluated together rather than as separate variables. By constructing a correlation matrix and performing Pearson's test for multicollinearity (Garson, 2006), we identified and summed together variables with correlation coefficients greater than 0.5 . Three groups of variables were combined using a summated Likert scale into 3 dummy variables: concern over water quality (WATERQUALITY), concern over animal welfare (ANIMALWELFARE), and concern over economics (ECONOMICS), where:

WATERQUALITY = contamination of water

+ field-spreading of manure + insecticide/herbicide use

$$
\text { + quality of ground water + manure storage; }
$$

ANIMALWELFARE = how animals are housed

+ whether animals have access to pasture

+ animal welfare; and

ECONOMICS = effect of proposed facility

on resident's property value + effect of proposed

facility on resident's view.

The other variables remaining independently in the analysis were years of residence in Charlotte (YEARSINCHARLOTTE), months in the past year lived in Charlotte (MONTHSINPASTYEAR), gender (GENDER), ownership of residence, acreage of residence (ACREAGE), proximity to proposed dairy site (PROXIMITY), and highest level of education (EDUCATION).

The third step in data analysis was to identify the variables that maximized the likelihood of correctly predicting whether a Charlotte resident would support or oppose the farmer's proposal. This analysis was accomplished using logistic regression, specifically the binary logit model, which was estimated using the statistical software package SPSS (Green, 1995; Norusis, 2004; Park, 2005). The responses of those that needed more information were not utilized, because the goal was to determine factors that were important to residents in their decision to support or not support the proposal. The dummy variables defined previously, WATERQUALITY, ANIMALWELFARE, and ECONOMICS, were included in the logit model. In addition, the model included the other demographic variables believed critical in individual decision-making. The logit model estimated is represented by the following equation:

$$
\begin{gathered}
\log (\mathrm{p} / 1-\mathrm{p})=\alpha+\mathrm{B}_{1}(\text { YEARSINCHARLOTTE }) \\
+\mathrm{B}_{2}(\text { MONTHSINPASTYEAR })+\mathrm{B}_{3}(\text { GENDER }) \\
+\mathrm{B}_{4}(\text { RESIDENCEOWNERSHIP })+\mathrm{B}_{5}(\text { ACREAGE }) \\
+\mathrm{B}_{6}(\text { PROXIMITY })+\mathrm{B}_{7}(\text { EDUCATION }) \\
+\mathrm{B}_{8}(\text { WATERQUALITY })+\mathrm{B}_{9}(\text { ANIMALWELFARE }) \\
+\mathrm{B}_{10}(\text { ECONOMICS })+\mathrm{e}
\end{gathered}
$$

where $\mathrm{p}=$ the probability of $\mathrm{Y}$ being 1 (supporting the LFO).

All variables in the model were categorical (dummy) except for YEARSINCHARLOTTE and MONTHSINPASTYEAR. The latter was intended to capture full or part-time residency but could not be defined categorically, because there was no theoretical basis for a cut- 
Table 1. Mean sociodemographics of respondent groups ${ }^{1}$

\begin{tabular}{|c|c|c|c|c|}
\hline \multirow[b]{2}{*}{ Item } & \multirow[b]{2}{*}{ Mean } & \multicolumn{3}{|c|}{ Category of response } \\
\hline & & Support & $\begin{array}{l}\text { Need more } \\
\text { information }\end{array}$ & $\begin{array}{l}\text { Do not } \\
\text { support }\end{array}$ \\
\hline $\mathrm{n}$ & & 90 & 53 & 130 \\
\hline Gender (\% female) & 50.2 & 50.0 & $55.1^{\mathrm{a}}$ & $47.7^{\mathrm{b}}$ \\
\hline Age $(y r)$ & 54 & 55 & 52 & 55 \\
\hline Education attained (BS, BA, or higher) & 80.1 & 76.2 & 76.0 & 84.9 \\
\hline Ownership of residence (\% own) & 97.9 & 98.9 & 100 & 98.4 \\
\hline Size of property ( $\% \geq 2 \mathrm{ha})$ & 63.3 & 67.0 & 56.0 & 64.1 \\
\hline Proximity ( $\%$ of residences $\geq 1.6 \mathrm{~km}$ from proposed site) & 82.1 & $81.2^{\mathrm{a}}$ & $94^{\mathrm{b}}$ & $76.6^{\mathrm{a}}$ \\
\hline Length of residence in Charlotte $(\mathrm{yr})$ & 19 & 23 & 19 & 15 \\
\hline Previous year residence in Charlotte (\% of full yr) & 76.5 & 79.8 & 76.5 & 80.6 \\
\hline
\end{tabular}

off number of months; hence, it was entered in the equation as a continuous variable.

\section{RESULTS AND DISCUSSION}

\section{Survey Response}

A $20.3 \%$ response rate is acceptable given the onetime mailing of the survey as a newspaper insert to all households and reliability of the sample obtained by that method (Johnson and Owens, 2004; Summerhill and Taylor, 1992). The characteristics of the respondents compared favorably to those of the town population based on US Census Bureau (2000) data except with respect to education. Although nearly $80 \%$ of the survey respondents held a bachelor's degree or higher level of education, census data (US Census Bureau, 2000) indicated that only $56 \%$ of Charlotte's population above the age of 25 had attained at least a bachelor's degree. One possible explanation for this finding is that the actual population of college graduates above age 18 is higher then the US Census estimate of college graduates above age 25 . Although this disparity suggests that survey respondents were more highly educated than the overall population in the town, we concluded that the sample was reliably representative of the town's adult population overall.

\section{Differences Between Respondent Categories}

Overall, $30.6 \%$ of the respondents supported the farm expansion (supporters), $44.3 \%$ opposed the plan (opponents or nonsupporters), and $17.9 \%$ said they needed more information before making a decision. A Student's $t$-test in SPSS identified the variables that had statistically different mean values among these 3 groups of respondents at $P<0.05$.

Sociodemographics. Means for the sociodemographics of the 3 groups are summarized in Table 1 .
The 3 groups of respondents did not differ demographically except in a few variables. The percentage of females that needed more information $(55.1 \%)$ was significantly higher than the percentage of females opposed $(47.7 \%)$ to the farm proposal. In addition, the percentage of residents needing more information who lived more than $1.6 \mathrm{~km}(1.0 \mathrm{mi})$ away from the farm (94\%) was higher than both the percentage of those in support (81.2\%) and those who opposed the farm proposal (76.6\%) and lived over $1.6 \mathrm{~km}$ (1.0 mi) away.

Although respondent groups did not differ significantly in the number of years of residence in Charlotte, it is noteworthy that residents in support of the farmer's proposal had resided in the town for $23 \mathrm{yr}$ compared with $15 \mathrm{yr}$ for residents who were opposed to it and $19 \mathrm{yr}$ for those who needed more information. There were no statistical differences based on age or education.

Concern over Agricultural Practices in Charlotte. Table 2 shows the scores for each group's level of concern about agricultural practices in Charlotte or concern about the proposed dairy facility. All topics were coded on a scale of $1=$ not at all concerned to $5=$ very concerned. Respondents who did not support the proposal indicated concern about all issues (because the overall average was above 3.25 in each case), and the level of concern differed between at least 2 groups on all issues.

Issues categorized as concern over water quality received the highest rankings overall (4.42), indicating moderate to high levels of concern among all groups of respondents. Nonsupporters reported consistently higher levels of concern than supporters (4.95 vs. 3.52). Overall concern over field-spreading of manure (2.97) was rated lower than concern over manure storage (4.17), suggesting that respondents did not perceive as great a risk to water quality from field-spreading as from manure storage. However, in Vermont, the 
Table 2. Mean scores ${ }^{1}$ for levels of concern of respondents over effects of agricultural practices in Charlotte ${ }^{2}$ or proposed dairy facility ${ }^{3}$

\begin{tabular}{|c|c|c|c|c|}
\hline \multirow[b]{2}{*}{ Item } & \multirow[b]{2}{*}{ Mean } & \multicolumn{3}{|c|}{ Category of response } \\
\hline & & Support & $\begin{array}{l}\text { Need more } \\
\text { information }\end{array}$ & $\begin{array}{l}\text { Do not } \\
\text { support }\end{array}$ \\
\hline Field-spreading of manure & 2.97 & $1.96^{\mathrm{a}}$ & $3.38^{\mathrm{b}}$ & $3.54^{\mathrm{c}}$ \\
\hline Manure storage & 4.17 & $3.03^{\mathrm{a}}$ & $4.46^{\mathrm{b}}$ & $4.88^{\mathrm{b}}$ \\
\hline Water contamination & 4.15 & $3.33^{\mathrm{a}}$ & $4.62^{\mathrm{b}}$ & $4.58^{\mathrm{b}}$ \\
\hline Ground or surface water quality & 4.42 & $3.52^{\mathrm{a}}$ & $4.79^{\mathrm{b}}$ & $4.95^{\mathrm{c}}$ \\
\hline Insecticide or herbicide use & 4.18 & $3.33^{\mathrm{a}}$ & $4.56^{\mathrm{b}}$ & $4.60^{\mathrm{c}}$ \\
\hline How animals are housed & 3.42 & $2.74^{\mathrm{a}}$ & $3.80^{\mathrm{b}}$ & $3.82^{\mathrm{b}}$ \\
\hline Providing animals with access to pasture & 3.10 & $2.51^{\mathrm{a}}$ & $3.23^{\mathrm{b}}$ & $3.50^{\mathrm{b}}$ \\
\hline Welfare of animals & 3.58 & $2.75^{\mathrm{a}}$ & $4.00^{\mathrm{b}}$ & $4.02^{\mathrm{a}}$ \\
\hline Effect on view & 2.89 & $1.93^{\mathrm{a}}$ & $3.23^{\mathrm{b}}$ & $3.47^{\mathrm{a}}$ \\
\hline Effect on property value & 3.07 & $2.11^{\mathrm{a}}$ & $3.10^{\mathrm{b}}$ & $3.68^{\mathrm{c}}$ \\
\hline Use of hormones & 4.04 & $3.36^{\mathrm{a}}$ & $4.37^{\mathrm{b}}$ & $4.39^{\mathrm{b}}$ \\
\hline Use of antibiotics & 3.95 & $3.28^{\mathrm{a}}$ & $4.17^{\mathrm{b}}$ & $4.34^{\mathrm{b}}$ \\
\hline Use of genetically modified seeds & 3.85 & $3.12^{\mathrm{a}}$ & $3.88^{\mathrm{b}}$ & $4.29^{\mathrm{c}}$ \\
\hline Disease transfer from animals to humans & 2.96 & $2.22^{\mathrm{a}}$ & $3.58^{\mathrm{b}}$ & $3.25^{\mathrm{b}}$ \\
\hline Health of neighboring residents & 3.98 & $2.60^{\mathrm{a}}$ & $4.45^{\mathrm{b}}$ & $4.72^{\mathrm{c}}$ \\
\hline
\end{tabular}

majority of stored liquid manure is spread twice a year. In the fall, it is after the period when plant growth can utilize nutrients, thus posing a greater risk for runoff and leaching, which would not happen if still in the pit. The concern over manure storage could reflect a lack of confidence in government-sanctioned recommendations, in this case by the Natural Resources Conservation Service, regarding manure pit construction (VAAFM, 2001).

Those not in support of the proposal ranked concerns over animal welfare (4.02 vs. 2.75) and economic effects (3.68 vs. 2.11) higher than supporters. Supporters had lower mean levels of concern for the effect of the LFO on animal welfare (2.75), their view (1.93), and property value $(2.11)$ than both nonsupporters (4.02, 3.47 , and 3.68, respectively) and those that needed more information (4.00, 3.23, and 3.10, respectively).

Use of hormones, antibiotics, and genetically modified seeds were consistently ranked as moderate concerns by nonsupporters. After water quality, the issue with the highest numerical ranking by supporters of the proposed dairy was the use of hormones (3.36). Both the nonsupporters and those needing more information expressed far greater concern over health of neighbors $(4.72,4.45)$ than over disease transfer from animals to humans $(3.25,3.58)$ This difference was not as pronounced among supporters of the proposal, whose level of concern over these issues was neutral to not very (2.60 and 2.22), perhaps because they have greater familiarity and comfort with modern dairy practices.

Attitudes Toward Converting Agricultural Land to Alternative Uses. When asked how willing they were to support alternative future uses of land in Charlotte that was currently open farmland or under pasture, all 3 respondent groups preferred keeping the land in small livestock farms (4.53) and small specialty crop farming (4.68) over converting it to residential (somewhat oppose) or industrial uses (2.12; Table 3). Of the farming alternatives, large livestock farming (2.80) was less preferred than small livestock farming or crop farming. Supporters of the dairy proposal indicated greater than moderate support for large-scale livestock farming (4.30), whereas nonsupporters somewhat opposed (1.73) this alternative.

Respondents' Assessment of Different Sources of Agricultural Information and Respondents' Farming Experience. The survey found that university affiliates (4.26) as well as farmers (4.51) were considered moderate to very reliable sources of agricultural information by all groups of respondents (Table 4). Nonetheless, supporters found farmers significantly more helpful than nonsupporters ( 4.79 vs. 4.32 ). Nonsupporters and those who needed more information ranked nonfarming neighbors (3.34 and 3.17) and not-for-profit organizations (3.99 and 3.87) as significantly more helpful sources of information than did supporters (2.43 and 3.17). We found that supporters 
Table 3. Mean scores ${ }^{1}$ for support of respondents of alternative uses for agricultural land in Charlotte

\begin{tabular}{lcccc}
\hline & & \multicolumn{3}{c}{ Category of response } \\
\cline { 3 - 5 } Item & Mean & Support & $\begin{array}{c}\text { Need more } \\
\text { information }\end{array}$ & $\begin{array}{c}\text { Do not } \\
\text { support }\end{array}$ \\
\hline Recreational use & 3.04 & $2.70^{\mathrm{a}}$ & $3.29^{\mathrm{b}}$ & 3.14 \\
Large livestock farms & 2.80 & $4.30^{\mathrm{a}}$ & $2.67^{\mathrm{b}}$ & $1.73^{\mathrm{c}}$ \\
Small livestock farms & 4.53 & $4.79^{\mathrm{a}}$ & $4.33^{\mathrm{b}}$ & $4.43^{\mathrm{b}}$ \\
Large crop farms & 3.79 & $4.61^{\mathrm{a}}$ & $3.67^{\mathrm{b}}$ & $3.22^{\mathrm{b}}$ \\
Small specialty crop farms & 4.68 & 4.75 & 4.46 & 4.73 \\
Small lot residences & 2.13 & 1.94 & 2.22 & 2.23 \\
Large lot residences & 2.42 & 2.15 & 2.52 & 2.53 \\
Light industrial use & 2.12 & 2.28 & 2.06 & 1.91 \\
\hline
\end{tabular}

${ }^{\mathrm{a}-\mathrm{c}}$ Means within a row with different superscripts differ $(P<0.05)$.

${ }^{1}$ Responses from those who were unaware of or uninterested in the proposed facility were excluded from the analysis. Scores were selected on a Likert scale of 1 to 5 , where $1=$ strongly oppose, $2=$ somewhat oppose, 3 = unsure or no opinion, 4 = somewhat support, and 5 = strongly support.

$(62.1 \%)$ had significantly greater experience with livestock farms than nonsupporters (43.1\%); however, experience with crop farms was nearly identical between supporters and nonsupporters. Residents who needed more information had significantly less livestock or crop farming experience (23.1 and $28.8 \%$ ) than the other 2 groups.

\section{Factors that Significantly Influence Respondents' Decisions to Support or Not Support the LFO Proposal}

Logistic regression identified variables that determined whether an individual supported (or did not support) the farmer's LFO proposal. Results from estimating the binary logit model are shown in Table 5 . A negative $\mathrm{B}(\beta)$ value means there was an inverse relationship between a particular variable and the decision to support the LFO. The $\operatorname{Exp}(\mathrm{B})$ is the antilog

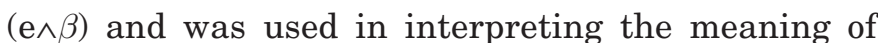
the regression coefficients (George and Mallery, 2001). The model correctly predicted $75.5 \%$ of the respondents' decisions to support or not support the LFO proposal.

As a resident's proximity to the proposed facility increases by $1.6 \mathrm{~km}(1.0 \mathrm{mi})$, the odds of the individual supporting the proposal increase $(P<0.05)$ by a factor of 2.8, holding other variables constant. As the length of time a resident had lived in Charlotte increases by a year, the odds for the resident supporting the LFO proposal (vs. not supporting it) increase by about $2 \%$ $(P<0.10)$, a factor of 1.02. None of the other sociodemographic variables (i.e., gender, ownership of residence, acreage owned, and education) were significant in the decision to support the dairy facility proposal.

Bivariate analysis had revealed that environmental and animal welfare concerns (Table 2) were important to the respondents of the survey who were not support-

Table 4. Mean scores ${ }^{1}$ reflecting how helpful respondents considered different sources of agricultural information

\begin{tabular}{lcccc}
\hline & & \multicolumn{3}{c}{ Category of response } \\
\cline { 3 - 5 } Item & Mean & Support & $\begin{array}{c}\text { Need more } \\
\text { information }\end{array}$ & $\begin{array}{c}\text { Do not } \\
\text { support }\end{array}$ \\
\hline Farmers & 4.51 & $4.79^{\mathrm{a}}$ & 4.48 & $4.32^{\mathrm{b}}$ \\
Nonfarming neighbors & 2.99 & $2.43^{\mathrm{a}}$ & $3.17^{\mathrm{b}}$ & $3.34^{\mathrm{b}}$ \\
Family members & 2.98 & $3.25^{\mathrm{a}}$ & $2.67^{\mathrm{b}}$ & 2.93 \\
Extension or university affiliates & 4.26 & 4.26 & 4.38 & 4.26 \\
Not-for-profit organizations & 3.68 & $3.17^{\mathrm{a}}$ & $3.87^{\mathrm{b}}$ & $3.99^{\mathrm{b}}$ \\
Government agencies & 3.28 & 3.19 & $3.52^{\mathrm{a}}$ & $2.28^{\mathrm{b}}$ \\
For-profit businesses & 2.32 & 2.34 & 2.46 & 2.19 \\
Percentage having farming experience & & & & $43.1^{\mathrm{c}}$ \\
On livestock farm & 50.0 & $62.1^{\mathrm{a}}$ & $23.1^{\mathrm{b}}$ & $39.2^{\mathrm{a}}$ \\
On crop farm & 38.1 & $38.6^{\mathrm{a}}$ & $28.8^{\mathrm{b}}$ & \\
\hline
\end{tabular}

${ }^{\mathrm{a}-\mathrm{c}}$ Means within a row with different superscripts differ $(P<0.05)$.

${ }^{1}$ Responses from those who were unaware of or uninterested in the proposed facility were excluded from the analysis. Scores were selected on a Likert scale of 1 to 5 , where $1=$ not at all, $2=$ not very, $3=$ unsure or no opinion, 4 = moderately, and 5 = very helpful. 
Table 5. Results of binary logit regression showing relationship between variables and the odds of supporting the dairy proposal

\begin{tabular}{|c|c|c|}
\hline Variable & $\mathrm{B}^{1}$ & $\begin{array}{l}\operatorname{Exp}(B)^{2} \text { or } \\
\text { odds ratio }\end{array}$ \\
\hline $\begin{array}{l}\text { Gender } \\
(\text { female }=1, \text { male }=0)\end{array}$ & 0.068 & 1.071 \\
\hline $\begin{array}{l}\text { Type of residence } \\
\text { (owned }=1 \text {, rented }=0 \text { ) }\end{array}$ & -1.543 & 0.214 \\
\hline $\begin{array}{l}\text { Size of property } \\
{[\geq 2.02 \text { ha }(5 \text { acres })=1,<2.02 \text { ha }(5 \text { acres })=0]}\end{array}$ & -0.029 & 0.972 \\
\hline $\begin{array}{l}\text { Proximity to farm with proposed large farm operations } \\
(>1.6 \mathrm{~km}=1, \leq 1.6 \mathrm{~km}=0)\end{array}$ & $1.018^{*}$ & 2.767 \\
\hline $\begin{array}{l}\text { Education } \\
\text { (postgraduate or professional }=1 \text {, bachelor's degree or less }=0 \text { ) }\end{array}$ & -0.147 & 0.863 \\
\hline $\begin{array}{l}\text { Years of residence in Charlotte } \\
\text { (Continuous) }\end{array}$ & $0.018 \dagger$ & 1.018 \\
\hline $\begin{array}{l}\text { Months in Charlotte in the past year } \\
\text { (continuous) }\end{array}$ & 0.050 & 1.051 \\
\hline $\begin{array}{l}\text { Concern over water quality } \\
\text { (top } 1 / 3 \text { of those that are concerned }=1 \text {, bottom } 2 / 3=0 \text { ) }\end{array}$ & $-2.905^{*}$ & 0.055 \\
\hline $\begin{array}{l}\text { Concern over economics } \\
\text { (top } 1 / 3 \text { of those that are concerned }=1 \text {, bottom } 2 / 3=0 \text { ) }\end{array}$ & -0.942 & 0.390 \\
\hline $\begin{array}{l}\text { Concern over animal welfare } \\
(\text { top } 1 / 3 \text { of those concerned }=1 \text {, bottom } 2 / 3=0 \text { ) }\end{array}$ & $-1.094^{*}$ & 0.335 \\
\hline
\end{tabular}

\footnotetext{
${ }^{1}$ The $\beta$ value (B) from the binary logit regression indicates the relationship between a particular variable and the decision to support the farm proposal.

${ }^{2}$ The $\operatorname{Exp}(\mathrm{B})$ is the antilog of $\beta\left(\mathrm{e}^{\wedge} \beta\right)$ and is used to interpret the meaning of the regression.

$\dagger P<0.10 ; * P<0.05$.
}

ers or needed more information. The results of the binary logit model bear this out by showing a level of significance for the variable WATERQUALITY $(P<$ $0.05)$. The $B$ value of -2.905 implies a negative correlation between respondents' concerns over water quality and the likelihood that they would support the dairy farm proposal. Hence, as the level of concern over water quality increases by 1 unit, the odds of that individual supporting the dairy facility decline by a factor of 2.9. Similarly, a resident's odds of supporting the LFO decline by a factor of $1.09(P<0.05)$ as that resident's concern for animal welfare increases from being in the lower 66.7 percentile to the top 33.3 percentile. For animal welfare, the results indicate a negative correlation between concern over animal welfare and support for the dairy farm proposal. Lastly, an individual's concern over economic variables (property value and the view) did not have a significant effect on their odds of supporting (or not supporting) the LFO. These logit results support our final hypothesis that respondents will be more concerned about environmental factors than economic factors. The odds of supporting the LFO significantly change with the respondents' levels of concern over water quality (an environmental factor), whereas change in concern over economic factors does not affect an individual's odds of supporting the LFO. Thus, we conclude that for the residents responding to the survey, environmental concerns outweigh economic concerns with respect to the effect of the proposed LFO in Charlotte.

General Perceptions of Respondents Toward Farmer, the Permitting Process, and Land Use Issues in Charlotte. Residents' comments on issues surrounding the proposed LFO (in response to an openended question at the end of the survey) revealed how individuals felt toward the proposing farmer personally and the permitting process. These attitudes may have played an important role in influencing individual decisions to support or not support the farmer's proposal. A specific question asking respondents if the permitting process adequately considered the concerns of area residents $(1=$ disagree, $5=$ agree $)$ revealed that nonsupporters (1.60) were less satisfied with the permitting process than supporters (4.19) and those who needed more information (2.85). In addition, some comments indicated that there were individuals who perceived the process as catering to farmers while excluding residents from contributing adequately to the decision to award or deny a permit. Yet, among supporters, most considered the process adequate, with some expressing the view that the farmer had acted within his rights as landowner.

Several nonsupporters and those that needed more information said that the farmer had not been open 
and honest about the ultimate size of the new dairy facility. Some indicated that they believed what had been presented was only the initial phase of the expansion and that the ultimate size would be 2 to 3 times larger. This suggested a lack of trust toward the farmer and may have caused some not to support the proposal. From the researchers' perspective, some of the mistrust may have resulted from a misinterpretation of cow numbers. It appears that the initial 684-cow farm with facilities to come later to house approximately 500 replacements was interpreted by some as a 1,200cow operation.

Several nonsupporters opined that given the glut in milk production nationwide, large dairy operations, such as the one proposed, tended to drive small dairy farmers out of business. They wondered why the farmer was willing to make such a huge investment given the conditions of the industry. Some supporters on the other hand said that although they were concerned about the size of the proposed LFO and its potential effects, they were even more concerned that if the farmer was unable to expand and modernize, he would subdivide the land for development, which in their opinion was a less attractive option.

Finally, the level of property taxes in Charlotte was viewed by all groups as a serious impediment to the survival of small farms in the town. Government subsidies to larger operations were viewed unfavorably by some nonsupporters, who said that wealthy farmers, such as the one proposing the LFO, did not need such subsidies to make a living yet continued to receive them.

\section{Implications for Other Dairy Farming Expansions}

The results of this study provide guidance for other farmers and extension educators in planning for 500to 700-cow dairy expansions within a growing suburban community. We suggest that because the proposal belongs to the farmer, he must take primary responsibility for addressing public concerns if the expansion is to receive favorable public response

Extension educators can play a critical role in providing the public with information and technical expertise on agricultural production and its potential effects. Given their long association with agricultural producers, extension personnel face a major challenge in appearing neutral when reaching out to nonagricultural citizen groups. These groups do not have a traditional association with extension and are quick to associate land grant educators as biased supporters of large-scale agriculture. Therefore, extension has a unique opportunity to provide public education but must take extra efforts to be seen as a neutral and honest broker to be effective when addressing environmental and technical issues.

The first point to remember from this analysis is that initial pubic reaction to the expansion as expressed in the local media was not a true representation of the community's sentiment. Judging from newspaper articles and letters to the editor, one would have expected to find nearly total opposition to the farm expansion. The study found $44.3 \%$ of survey respondents were opposed to the farm, whereas $30.6 \%$ supported the farm expansion. The lesson from this survey is that the opposition is much more vocal than supporters. We could not protect against reporting bias from this group of motivated residents, possibly resulting in the overestimation of opponents to the dairy proposal by our survey. In addition, there is a substantial group that asked critical questions but had not made up their minds. Dairy farmers should identify ways to reach this crucial group as they seek to gain support for expansion plans. Educators can provide technical information to those asking specific questions.

The recommendations for farmers from this study can be summarized as follows. First, farmers must be proactive in getting information to neighbors about the expansion. If the farmer does not provide information, those opposed to the farm will release information supporting their arguments. Farmers should realize that some people will oppose the plan no matter what information is presented but understand there is probably more support than can be readily perceived. Second, farmers must anticipate concerns over water quality and address these concerns specifically. Farmers should develop and explain their plan for manure management and how it meets or exceeds applicable state or federal guidelines. Positive environmental effects should be highlighted. Third, farmers need to take the time to develop a plan on how to distribute this information to neighbors to help reduce fears and encourage dialogue. Keeping in mind that major corporations hire public relations firms, farmers would benefit from advice from other farmers who have undergone expansions or from farm organizations that have addressed public relations. Those opposed to farm expansions can organize quickly and will likely be spreading their own message, so having a communication and "marketing" plan in place early in the process will increase the odds of favorable public reception of the plan. Farmers need to be aware that although the findings of this study may inform discourse over 500to 700-cow expansions, public perception and response to even larger operations may be much different.

\section{CONCLUSIONS}

The public is greatly concerned about the effect of agricultural activities, including modern dairy farm- 
ing, on their environment and communities. The objections raised by Charlotte residents are consistent with those raised by other communities neighboring livestock farms (Jones et al., 2000; Kelsey and Vaserstein, 2000; Aillery et al., 2005). Yet, residents often rely on limited or inaccurate information on modern farm practices when making decisions to support or not support farmers. This study reveals that residents in Charlotte consider environmental factors, including water quality and animal welfare, of utmost concern with regard to large dairy farming operations. Given current demographic and dairy industry trends, conflicts between farmers and their neighbors such as that took place in Charlotte will likely increase in frequency. As dairy farmers are building more capitalintensive operations with larger herd sizes as a result of economic forces and technological advances (Blayney and June, 2002; Short, 2004), more residential developments are becoming established in rural or farming localities, particularly in areas, like Charlotte, that lie in close proximity to urban centers $(\mathrm{Gu}-$ they et al., 2003; Roe et al., 2004). This study points to the need to better understand the factors that are most objectionable to residents with respect to large dairy operations. The findings show that there is likely to be a sizable proportion of residents who do support the farm and a very important group that needs more information before deciding to support or oppose dairy farm modernization plans. Studies have shown that agricultural extension services can play an important role in providing accurate information about farming practices to communities (Sharp et al., 2002). Because farmers and individuals affiliated with universities were reliable and helpful sources of agricultural information, they might be able to play a more active role in communicating important facts to residents, thereby reducing or mitigating conflict. Proactive farmer involvement in developing a public relations plan and anticipating concerns and questions from neighbors is recommended when planning a dairy expansion.

\section{ACKNOWLEDGMENTS}

We thank Fred Schmidt of the Center for Rural Studies at the University of Vermont and others with University of Vermont Extension for their assistance with development of the survey instrument. This project was conducted with partial support from the University of Vermont Extension and Vermont Agricultural Experiment Station.

\section{REFERENCES}

Agreseti, A., and B. Finlay. 1997. Statistical Methods for the Social Sciences. 3rd ed. Prentice Hall, Upper Saddle River, NJ.
Aillery, M., N. Gollehon, R. Johansson, J. Kaplan, N. Key, and M. Ribaudo. 2005. Managing manure to improve air and water quality. Economic Research Report 9. USDA Econ. Res. Serv. USDA, Washington, DC.

Blayney, D., and P. June. 2002. The changing landscape of United States milk production. Statistical Bulletin SB978. USDA Econ. Res. Serv. USDA, Washington, DC.

CFSF. 2003. Citizens for Safe Farming. http://www.safefarming.org Accessed May 15, 2005.

Environmental Protection Agency. 2006. New England Total Maximum Daily Load (TMDL). http://epa.gov/region1/eco/tmdl/index.html Accessed Mar. 14, 2006.

Garson, D. 2006. Correlation. http://www2.chass.ncsu.edu/garson/ PA765 /correl.htm Accessed May 8, 2006.

George, D., and P. Mallery. 2001. SPSS for Windows: A Simple Guide and Reference, 10.0 Update. 3rd ed. Allyn and Bacon, Boston, MA

Gollehon, N., M. Caswell, M. Ribaudo, R. Kellogg, C. Lander, and D. Letson. 2001. Confined animal production and manure nutrients. Agriculture Information Bulletin AIB771. USDA, Washington, DC.

Green, W. H. 1995. LIMDEP Version 7.0 Reference Guide. Econometric Software Inc., Bellport, NY.

Guthey, T. G., L. Gwin, and S. Fairfax. 2003. Creative preservation in California's dairy industry. Geogr. Rev. 93:171-192.

Johnson, T., and L. Owens. 2004. Pages 127-133 in Survey response rate reporting in the professional literature. Am. Assoc. Public Opin. Res., Chicago, IL.

Jones, K., T. W. Kelsey, P. A. Nordstrom, L. L. Wilson, A. N. Maretzki, and C. W. Pitts. 2000. Neighbors' perceptions of animal agriculture. Prof. Anim. Sci. 16:105-110.

Kelsey, T. W., and G. Vaserstein. 2000. Farming and non-farming neighbors: Conflict, coexistence, and communication. J. Soil Water Conserv. 55:462-466.

Kryvoruchko, V., T. Amon, and S. Zechmeister-Boltenstern. 2006. Methane, nitrous oxide and ammonia emissions during storage and after application of dairy cattle slurry and influence of slurry treatment. Agric. Ecosyst. Environ. 112:153-162.

Lake Champlain Basin Program. 2006. Lake Champlain Basin Program. http://www.lcbp.org Accessed Mar. 14, 2006.

Lefcourt, A., and J. Meisinger. 2002. Keeping manure nutrients down on the farm. Agric. Res. 50:15-16.

Norusis, M. J. 2004. SPSS 12.0 Guide to Data Analysis. Prentice Hall, Upper Saddle River, NJ.

Park, H. M. 2005. Categorical Dependent Variable Models Using SAS, STATA, LIMDEP, and SPSS. http://www.iu.edu/ statmath/ Accessed Feb. 26, 2006.

Roe, B., E. G. Irwin, and H. A. Morrow-Jones. 2004. The effects of farmland, farmland preservation, and other neighborhood amenities on housing values and residential growth. Land Econ. 80:55-75.

Sharp, J., E. Imerman, and G. Peters. 2002. Community supported agriculture (CSA): Building community among farmers and nonfarmers. http://www.joe.org/joe/2002june/a3.html Accessed Apr. $15,2005$.

Short, S. D. 2004. Characteristics and production costs of US dairy operations. USDA Economic Research Service Statistical Bulletin 974-6. USDA, Washington, DC.

Summerhill, W. R., and C. L. Taylor. 1992. Selecting a data collection technique. Circular PE-21. Florida Coop. Extension Serv., Univ. Florida, Gainesville.

US Census Bureau. 2000. D.P-2. Profile of selected social characteristics: 2000. Data set: Census 2000 summary file (3) SF-3 Sample data: Geographical area: Charlotte town, Chittenden County, Vermont.

USDA. 2002. Census of Agriculture. www.agcensus.usda.gov/Publi cations/2002/census-by-state/Vermont/ Accessed Mar. 15, 2005.

VAAFM. 2001. Vermont Agency of Agriculture, Food and Markets: Large Farm Operations (LFO). Regulation: 30. www.vermont agriculture.com/ARMES/awg/LFO.html Accessed Jan. 30, 2006. 
Van Dis, K. 2006. The role of environmental and demographic factors in dairy farm expansion at the rural/urban fringe: The case of Charlotte, Vermont. MS Thesis. Univ. Vermont, Burlington.
Vaserstein, G., and T. Kelsey. 2000. Neighbors' perceptions of mushroom farms at the rural/urban interface. Compost Sci. Util. 8:310-316.

\section{The \\ 语 UNIVERSITY of VERMONT}

\section{APPENDIX}

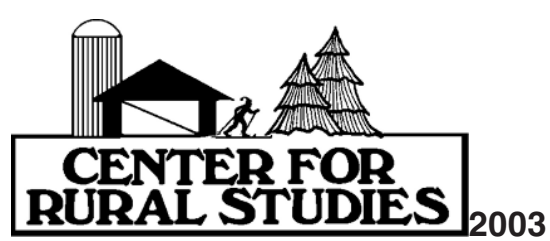

\section{SURVEY: AGRICULTURE AND LAND USE IN CHARLOTTE}

UVM Extension and UVM's Center for Rural Studies are conducting a survey to assess current attitudes toward agriculture and land use in the town of Charlotte. The results will be used to develop educational programs. Summaries of the results will be shared with your community.

Please have the household member with the most recent birthday who is also at least 18 years of age complete the survey. This is to minimize age bias. You will need about 10 minutes to fill it out. Your taking the time to complete and return this survey is greatly appreciated.

All individual responses will remain confidential. Only summarized data will be reported. Personal and household information is requested to ensure that our survey responses are representative of the community. Results will be shared with the town planning and zoning board. Copies of the results will be available upon request. Any questions about this survey should be directed to Dr. Julie Smith, Department of Animal Science, 802-656-2070.

Please have the household member with the most recent birthday who is also at least $18 \mathrm{yr}$ of age complete the survey.

1. Do you live in Charlotte at least part of the year? Yes No

If you answered "NO" to question 1, do not complete the survey. Please fold and return it. Thank you.

2. a. How many years have you lived in Charlotte? (Count any part of a calendar year as one year.)

b. How many of the past 12 months have you physically resided in Charlotte? months

3. Have you ever owned or worked on a farm with livestock or horses? Yes No

4. Have you ever owned or worked on a farm with vegetable, fruit, grain, or tree crops? Yes No

5. How willing are you to support the following future uses of land that is currently open farmland and pasture in the town of Charlotte? (Please circle your choice from $5=$ "strongly support" to $1=$ "strongly oppose".)

\begin{tabular}{|c|c|c|c|c|c|c|}
\hline & $\begin{array}{l}\text { Strongly } \\
\text { support }\end{array}$ & $\begin{array}{c}\text { Somewhat } \\
\text { support }\end{array}$ & $\begin{array}{l}\text { Unsure or } \\
\text { neutral }\end{array}$ & $\begin{array}{c}\text { Somewhat } \\
\text { oppose }\end{array}$ & $\begin{array}{c}\text { Strongly } \\
\text { oppose }\end{array}$ & $\begin{array}{c}\text { No } \\
\text { opinion }\end{array}$ \\
\hline Develop ag land for small lot residences & 5 & 4 & 3 & 2 & 1 & 0 \\
\hline Convert ag land for recreation uses (eg: golf course, park) & 5 & 4 & 3 & 2 & 1 & 0 \\
\hline Convert ag land for light industrial use & 5 & 4 & 3 & 2 & 1 & 0 \\
\hline Use for large crop farms & 5 & 4 & 3 & 2 & 1 & 0 \\
\hline Use for small specialty crop farms & 5 & 4 & 3 & 2 & 1 & 0 \\
\hline
\end{tabular}

6. Please indicate your level of concern about the following agricultural issues in the town of Charlotte by circling your choice. Use the following scale from $4=$ "very concerned" to 1 = "not at all concerned." 


\begin{tabular}{|c|c|c|c|c|c|}
\hline & $\begin{array}{c}\text { Very } \\
\text { concerned }\end{array}$ & Moderately & $\begin{array}{l}\text { Not } \\
\text { very }\end{array}$ & $\begin{array}{l}\text { Not } \\
\text { at all }\end{array}$ & $\begin{array}{l}\text { Unsure or } \\
\text { no opinion }\end{array}$ \\
\hline Contamination of water & 4 & 3 & 2 & 1 & 0 \\
\hline How animals are housed & 4 & 3 & 2 & 1 & 0 \\
\hline Allowing animals access to pasture & 4 & 3 & 2 & 1 & 0 \\
\hline Use of hormones & 4 & 3 & 2 & 1 & 0 \\
\hline Use of antibiotics & 4 & 3 & 2 & 1 & 0 \\
\hline Use of genetically modified organism seeds & 4 & 3 & 2 & 1 & 0 \\
\hline
\end{tabular}

7. Are you concerned about any other agricultural issues or practices in your town? If so, please specify

8. Are you engaged in any of the following activities in your community? (Check all that apply.)

$\bigcirc$ Vote in local elections

Serve on fire, police, or ambulance squad

Hold office or serve on local town or school board or committee

Belong to service or membership association (Rotary, VFW, etcetera)

Please specify

$\bigcirc$ Participate in community activities (through school, church, 4-H, and so on)

Please specify

9. Please indicate (by circling) how likely you would be to obtain information on agricultural issues by each of the following means. (Rank from 4 = "very likely" to 1 = "not at all likely.")

\begin{tabular}{|c|c|c|c|c|c|}
\hline & $\begin{array}{l}\text { Very } \\
\text { likely }\end{array}$ & Moderately & $\begin{array}{l}\text { Not } \\
\text { very }\end{array}$ & $\begin{array}{l}\text { Not } \\
\text { at all }\end{array}$ & $\begin{array}{l}\text { Unsure or } \\
\text { no opinion }\end{array}$ \\
\hline Fact sheet or informational pamphlet & 4 & 3 & 2 & 1 & 0 \\
\hline News feature (newspaper, radio, or television) & 4 & 3 & 2 & 1 & 0 \\
\hline Textbook & 4 & 3 & 2 & 1 & 0 \\
\hline Panel discussion & 4 & 3 & 2 & 1 & 0 \\
\hline Forum (lecture series) & 4 & 3 & 2 & 1 & 0 \\
\hline Farm tours & 4 & 3 & 2 & 1 & 0 \\
\hline Web site & 4 & 3 & 2 & 1 & 0 \\
\hline
\end{tabular}

10. Please indicate how helpful each of the following people or organizations might be to your understanding of agricultural issues (from 4 = "very helpful" to 1 = "not at all helpful"). Please answer as if the sources were local or Vermont-based.

\begin{tabular}{lccccc}
\hline & $\begin{array}{c}\text { Very } \\
\text { likely }\end{array}$ & Moderately & $\begin{array}{c}\text { Not } \\
\text { very }\end{array}$ & $\begin{array}{c}\text { Not } \\
\text { at all }\end{array}$ & $\begin{array}{c}\text { Unsure or } \\
\text { no opinion }\end{array}$ \\
\hline Farmers & 4 & 3 & 2 & 1 & 0 \\
Non-farming neighbors & 4 & 3 & 2 & 1 & 0 \\
Family members & 4 & 3 & 2 & 1 & 0
\end{tabular}




\begin{tabular}{llllll} 
Extension/university specialists/professors & 4 & 3 & 2 & 1 & 0 \\
Not-for-profit corporations/organizations & 4 & 3 & 2 & 1 & 0 \\
Government agencies & 4 & 3 & 2 & 1 & 0 \\
For-profit corporations/businesses & 4 & 3 & 2 & 1 & 0 \\
\hline
\end{tabular}

11. Please name any local voluntary organizations that could potentially host an educational forum related to agriculture or land use:

12. A 680-cow dairy facility was proposed in Charlotte in 2002. Which of these statements describes your opinion of the proposal? (Check one.)

$\bigcirc$ Don't know about it. (If so, please skip to question 16.)

$\bigcirc$ Know about it but need more information to form an opinion.

$\bigcirc$ Know about it and support it.

$\bigcirc$ Know about it and don't care how it turns out.

$\bigcirc$ Know about it and oppose it.

13. How far is your property from the site of the proposed new dairy facility?
Don't know
1 mile or less
Over 1 mile

14. Regarding the proposed dairy facility, what is your level of concern about the following issues? (Rank from 4 = "very concerned" to 1 = "not at all concerned.")

\begin{tabular}{|c|c|c|c|c|c|c|}
\hline & & $\begin{array}{c}\text { Very } \\
\text { concerned }\end{array}$ & Moderately & $\begin{array}{l}\text { Not } \\
\text { very }\end{array}$ & $\begin{array}{l}\text { Not } \\
\text { at all }\end{array}$ & $\begin{array}{l}\text { Unsure or } \\
\text { no opinion }\end{array}$ \\
\hline a. & Economic viability of the farm & 4 & 3 & 2 & 1 & 0 \\
\hline b. & Quality of ground water or surface water & 4 & 3 & 2 & 1 & 0 \\
\hline c. & Manure storage & 4 & 3 & 2 & 1 & 0 \\
\hline d. & Health of people living near farm & 4 & 3 & 2 & 1 & 0 \\
\hline e. & Effect on view & 4 & 3 & 2 & 1 & 0 \\
\hline f. & Noise & 4 & 3 & 2 & 1 & 0 \\
\hline g. & Flies and other insects & 4 & 3 & 2 & 1 & 0 \\
\hline h. & Dust & 4 & 3 & 2 & 1 & 0 \\
\hline i. & Odor & 4 & 3 & 2 & 1 & 0 \\
\hline j. & Disposal of dead animals & 4 & 3 & 2 & 1 & 0 \\
\hline $\mathrm{k}$. & Welfare of the animals & 4 & 3 & 2 & 1 & 0 \\
\hline 1. & Property value & 4 & 3 & 2 & 1 & 0 \\
\hline $\mathrm{m}$. & Truck traffic & 4 & 3 & 2 & 1 & 0 \\
\hline $\mathrm{n}$. & Other (specify) & 4 & 3 & 2 & 1 & 0 \\
\hline
\end{tabular}

15. For the issues listed in question 14, please indicate your top 3 concerns by listing below the corresponding letter:

Top concern:

Second highest concern:

Third highest concern:

16. Do you agree that the current permitting process will adequately take into consideration the concerns Charlotte citizens have about the proposed dairy facility? (Rank from 5 = "agree" to 1 = "disagree.") 


\begin{tabular}{lccccc}
\hline Agree & $\begin{array}{c}\text { Somewhat } \\
\text { agree }\end{array}$ & Unsure & $\begin{array}{c}\text { Somewhat } \\
\text { disagree }\end{array}$ & Disagree & $\begin{array}{c}\text { No } \\
\text { opinion }\end{array}$ \\
\hline 5 & 4 & 3 & 2 & 1 & 0 \\
\hline
\end{tabular}

17. What would you do if you owned 1000 acres of farmland in Charlotte?

18. Is there anything else you would like to tell us?

We would appreciate the following information to verify that our survey responses are representative of the community.

Are you? $\square$ Male $\square$ Female

What year were you born?

What is your occupation?

What is the highest level of education you have completed?

Is your residence $\square$ Owned $\square$ Rented

Is the area of the land 5 or more acres? $\square$ Yes $\square$ No

UVM Extension and the Center for Rural Studies thank you for participating in this survey. 